\title{
Álitamál tengd innleiðingu hæfnimiðaðs námsmats í skyldunámi
}

\author{
Meyvant Dórólfsson
}

Abstract $\backslash$ Um höfund $\longrightarrow$ About the author $\rightarrow$ Heimildir

\begin{abstract}
Rannsóknastofa um námskrár, námsmat og námsskipulag stód fyrir tveimur málpingum um námskrár og námsmat á vordögum 2019. Gestur fyrra málpingsins var hollenski námskrárfræðingurinn Jan van den Akker og á seinna málpinginu fluttu fimm hérlendir sérfræðingar erindi um innleiðingu nýs námsmatskerfis í skyldunámi. Undanfarin misseri hefur átt sér stað umræða um petta kerfi eins og pað var kynnt í núgildandi aðalnámskrá fyrir skyldunám. Skotið hafa upp kollinum áhugaverð álitamál og spurningar pessu tengdar. Dar má í fyrsta lagi nefna spurninguna um miðlæga samræmingu hæfniviðmiða og mats. Í öðru lagi beinast augu manna að faglegri ábyrgð kennara og um leið vaxandi vinnuálagi peirra við námsmat sem er samofið námi og kennslu. Í priðja lagi parf að gefa nýjum hugtökum gaum og beitingu peirra eða öllu heldur nýjum orðum yfir kunnugleg hugtök. Í fjórða lagi koma við sögu gamalkunnar hugmyndastefnur í námskrárfræðum og áhrif peirra á setningu markmiða og hæfniviðmiða. Loks hafa vaknað spurningar um samband leiðsagnarmats og lokamats og aðferðir par að lútandi. Markmið greinarinnar er að rýna nánar í pessi álitamál með vísan í rannsóknir og kenningar annars vegar og hins vegar erindi peirra sem töluðu á málpingunum. Meginniðurstaða höfundar er að víðtækt mat á hæfni hljóti að stuðla að auknu réttmæti og par með sanngjarnara mati öllum til meiri hagsbóta en áður tíðkaðist. Að sama skapi krefst framkvæmd slíks mats aukinnar matsfræðipekkingar og faglegrar ábyrgðar kennara og stjórnenda. Um leið má pó ljóst vera að viðmið um hæfni og mat í hinu nýja kerfi eru á margan hátt óljós og pví auknar líkur á ósamræmi í mati frá einum skóla til annars.
\end{abstract}

Efnisorð: Námskrárinnleiðing, námsmat, hæfni, hæfniviðmið, lokamat, leiðsagnarmat

\section{Inngangur}

Allt frá pví núgildandi aðalnámskrár komu til framkvæmda hér á landi fyrir öll skólastig virðist ýmislegt tengt innleiðingu peirra hafa valdið peim heilabrotum sem hafa átt hlut að máli (Jón Pétur Zimsen, 2019). Í pví ljósi hefur mönnum sérstaklega verið tíðrætt um hið hæfnimiðaða matskerfi eins og pví er lýst í núgildandi aðalnámskrá fyrir skyldunám (Mennta- og menningarmálaráđuneytið, 2013) og útfærslu pess. Á vordögum 2019 stóð Rannsóknastofa um námskrár, námsmat og námsskipulag (NNN Rannsóknastofa) fyrir tveimur málpingum um pessi mál. Á pví fyrra, sem fram fór 25. mars, ræddi hollenski námskrárfræðingurinn Jan van den Akker um stóra samhengið í námskrárpróun á heimsvísu. Erindi sitt nefndi hann The Interconnected 
Curriculum, par sem hann ræddi samhengið milli mismunandi stiga menntakerfisins og tók síðan pátt í umræðum á eftir. Seinna málpingið bar yfirskriftina Samræmt hæfnimatskerfi í skyldunámi: Menntaumbót eða bókhaldsbaggi? Lokamat - Leiðsagnarmat - Mat samtvinnað námi og kennslu. Dar fluttu fimm sérfræðingar erindi, pau Hulda Dögg Proppé kennari við Sæmundarskóla í Reykjavík, Jón Pétur Zimsen fyrrverandi skólastjóri Réttarholtsskóla og ráðgjafi mennta- og menningarmálaráðherra, Linda Heiðarsdóttir aðstoðarskólastjóri Réttarholtsskóla, Rúnar Sigbórsson prófessor við Háskólann á Akureyri og Sverrir Óskarsson sviðsstjóri hjá Menntamálastofnun. Upptaka er til frá pessu málpingi og er vitnað í hana í heimildaskrá undir heiti rannsóknastofunnar (NNN Rannsóknastofa, 2019). Í kjölfar erinda seinna málpingsins fóru fram pallborðsumræður. Efni fundanna vakti að vonum fjölmargar spurningar um námskrárpróun, vanda við innleiðingu námskrárbreytinga, hugmyndafræðileg rök breytinganna, merkingu hugtaka, mismunandi tilgang námsmats, faglega ábyrgð kennara og síðast en ekki síst hvernig „námsmenning" einstakra skóla tengdist innleiðingunni.

Nýbreytni með tilheyrandi námskrárendurskoðun (e. curriculum reform) er sennilega eitt pekktasta prástef námskrárfræða og hafa fjölmargir sérfræðingar á pví sviði rannsakað og fjallað um petta fyrirbæri frá ýmsum sjónarhornum (sjá t.d. Elmore og McLaughlin, 1988; Fullan, 2001; Cuban, 2009; Hargreaves og Fullan, 2012). Ef niðurstöður rannsókna á pessu sviði eru dregnar saman má segja að tilvitnun van den Akker í skrif Hargreaves og Fink (2006) á fundinum 25. mars lýsi peim allvel, að ævinlega reynist auðvelt og 1 raun sjálfsagt að leggja til breytingar frá pví sem nú er. Degar komi að innleiðingu mæti mönnum pó margvíslegar hindranir og pað sem meira er, að ósjaldan reynist ógerningur að festa breytingarnar í sessi og viðhalda peim. Í lok pessarar greinar er petta fyrirbrigði tengt próun aðalnámskrárgerðar á Íslandi undanfarin 60 ár.

Ástæður slíkra hindrana telja menn margvíslegar. Algengasta skýringin er án efa sú, að oft skorti traust og skilning á milli peirra sem boða breytingarnar og peirra sem ætlað er að framkvæma pær. Раð er bæði gömul saga og ný, að ofansæknar (e. top-down) tilraunir til breytinga falli ekki alltaf greiðlega að fagvitund kennara og annarra sem eiga hagsmuna að gæa á vettvangi skólastarfs; peir meðtaki pær pví treglega (Fullan og Hargreaves, 1991; Hargreaves og Fullan, 2012). Niðurstöður rannsóknar Pietarinen, Pyhältö og Soini (2017) á kerfisbundnum námskrárbreytingum í Finnlandi gáfu til kynna að samráð og sameiginlegur skilningur allra hagsmunaaðila skipti vissulega sköpum, en dygði pó ekki til að innleiðing gengi greiðlega fyrir sig. Einnig pyrfti að huga að ýmsum flóknum páttum er tengdust samstillingu nýjunga við pá skólamenningu og vinnubrögð sem fyrir væru.

Langt er síðan Michael Fullan (1989) benti á hversu óraunhæft væri að halda að ein afmörkuð kerfisbreyting gæti verið í gangi hverju sinni, heldur væri endurskoðun og próun skólastarfs stöðugt og margslungið ferli; nýbreytnistarf á hverjum tíma ætti sér margar rætur og birtingarmyndir. Próunarstarfi skóla verður pví best lýst sem síkviku (dýnamísku). Skólar eru stöđugt að próa sérstöđu sína og áherslur á ýmsum sviðum. Hér á landi hafa sumir skólar til dæmis svonefnda uppbyggingarstefnu að leiðarljósi, sem byggir á hugmyndum Diane C. Gossen (2001); aðrir byggja á atferlismótunarhugmyndum eins og PBS (e. positive behavior support), sem George Sugai og Rob Horner próuðu við Háskólann í Oregon undir lok síðustu aldar (Sugai og Horner, 2009). Auk pess leitast fjölmargir við að marka sér sérstöðu hvað varðar skapandi starf, sampættingu námssviða, heilsueflandi skólastarf og fleira. Samhliða slíku próunarstarfi gangast skólar reglulega undir ofansæknar breytingar á borð við pá nýbreytni sem hér er fjallað um undir merkjum hæfnimiðaðs námsmats.

Hér er ekki um hefðbundna empíríska rannsóknargrein að ræða byggða á hefðbundnum rannsóknarspurningum eða tilgátum. Hins vegar má segja að viðfangsefnið (e. research problem) sé framangreind álitamál tengd innleiðingu námskrárbreytinga, hugtök og hugmyndir sem par koma við sögu og fagleg ábyrgð kennara og annarra hlutaðeigandi við innleiðinguna. Höfundur taldi einnig gagnlegt að taka eins konar söguvitund inn í myndina, p.e. að tengja pessi álitamál varðandi próun náms og námsmats í fortíð, nútíð og framtíð með eftirfarandi spurningu að leiðarljósi: Er hér á ferðinni „gamalt vín á nýjum belgjum“ eða raunveruleg nýbreytni? 
Í pessum inngangskafla hefur markmið og efni greinarinnar verið kynnt stuttlega. Par á eftir er kaflinn Smættun eða heildarsýn? Með honum er reynt að varpa ljósi á mikilvæg hugtök námskrárbróunar og eðli peirra, p.e. námsmarkmið og hæfniviðmið, og pað hvernig pau birtast í ljósi smættarhyggju annars vegar og heildarhyggju hins vegar. Dar á eftir fylgir kaflinn Innleiðing núgildandi aðalnámskrár, par sem námskrárbróun er reifuð með tilliti til helstu stiga skólakerfisins. Pví næst er kaflinn Hæfni, hæfniviðmið og matsviðmið, par sem pessi hugtök eru skoðuð í sögulegu samhengi. Á eftir honum er kaflinn Faglegt sjálfstæði kennara og tilgangur námsmats, sem ætlað er að varpa ljósi á vaxandi faglega ábyrgð kennara við leiðsagnarmat og lokamat. Loks er kaflinn Samantekt og ályktanir.

\section{Smættun eða heildarsýn?}

Í athyglisverðri samantekt Atla Harðarsonar, Stefna i námskrármálum og faglegt sjálfstcðði kennara (Atli Harðarson, 2015), varpaði höfundur fram pessari áhugaverðu fullyrðingu: „Thorndike vann og Dewey tapaði“. Par vísaði Atli til skrifa bandaríska sagnfræðingsins Ellen Condliffe Lagemann (1989) pess efnis að vestræn skólakerfi hefðu að miklu leyti mótast af andstæðum kenningum pessara tveggja fræðimanna, sem störfuðu samtímis við sömu háskólastofnun í Bandaríkjunum á fyrri hluta síðustu aldar. Hugmyndafræði Edward Thorndikes hafi með öðrum orðum feng¡ð góðan byr í vestrænum menntakerfum, en prátt fyrir að hugmyndafræði Dewey hafi hlotið jákvæða athygli og umræðu, hafi hún ekki birst í framkvæmd skólastarfs nema að takmörkuðu leyti. Lagemann taldi ógerlegt að skilja sögu skólamála í Bandaríkjunum nema gera sér grein fyrir pessu. Рað er áleitin spurning, hvort pað sama hafi gilt um sögu skólamála hérlendis og síðast en ekki síst, hvort núgildandi aðalnámskrá fyrir skyldunám beri pess merki að Thorndike hafi unnið en Dewey tapað?

Edward Thorndike var talsmaður tæknihyggju, sundurgreindrar markmiðssetningar og sálmælinga par sem aðferðir vísindanna skyldu hafðar að leiðarljósi. John Dewey hafnaði reyndar ekki aðferðum vísinda, enda tók hann meðal annars mið af próunarkenningu Charles Darwin í kenningum sínum (Atli Harðarson, 2016; Perricone, 2006) og hugmyndum úr lífvísindum. Hann leit hins vegar svo á að menntun væri flóknara félagslegt fyrirbrigði en svo að hana mætti sundurgreina og fella undir mælanleg markmið. Í raun væri ógerningur að lýsa markmiðum fyrirfram af pví nemendur væru ólíkir hvað varðaði proska, sem pýddi að námsferli hvers og eins hlyti að vera ófyrirséð. Dess vegna væri eðlilegast að meta nemendur og aðstæður peirra heildrænt.

Í raun má segja að munurinn á kenningum Thorndike og Dewey liggi í muninum á svonefndri smættarhyggju (e. reductionism) og heildarhyggju (e. holism). Smættarhyggja snýst um að greina fyrirbæri í hluta og meta frekar hlutana hvern fyrir sig en heildina. Sundurgreind pekkingarmarkmið og stöðluð pekkingarpróf að hætti Thorndike og fleiri atferlissinna koma pví heim og saman við smættarhyggju. Samkvæmt heildarhyggju skiptir á hinn bóginn mestu að skoða og meta allt í heildarsamhengi, enda telja heildarhyggjusinnar að slíkt mat leiði í ljós mikilvæg atriði um heildina sem gildi ekki endilega um hluta hennar; heildin feli sem sagt í sér eitthvað sem sé ekki endilega að finna í hlutum hennar. Detta rímar vel við hugmyndir Dewey sem vildi meta alhliða proska manneskjunnar og pað félagslega samhengi, sem hún tilheyrði, í heild sinni.

Með tilliti til innleiðingar pess matskerfis sem hér er til umfjöllunar er við hæfi í pessu tilliti að taka inn í myndina hugtökin greinandi mat og einkunnagjöf (e. analytic scoring) annars vegar og heildrænt mat og einkunnagjöf (e. holistic scoring) hins vegar. Tölfræði og raðeinkunnir (e. relative grading) eiga vel við pað fyrra, en hæfnimiðaðar bókstafaeinkunnir standa hinu nær, pótt deila megi um hvort pað matskerfi sem boðað er í núgildandi aðalnámskrá sé heildrænt og huglægt eða ekki. Í Aðalnámskrá grunnskóla (Mennta- og menningarmálaráðuneytið, 2013) er að finna yfir 200 hæfniviðmið sem krefjast greinandi mats, p.e. að hver hæfnipáttur fyrir sig sé metinn, sem hlýtur að heimfærast á smættarhyggju. Í pví sambandi má benda á notkun svonefndra hæfnikorta, sem víða eru í notkun í skólum; notkun peirra mun reyndar einnig gera rád fyrir heildrænu mati eins og vikið var að í erindum á seinna málpinginu. Pannig má ætla að ákvæði námskrárinnar um mat á hæfni geri bæði ráð fyrir bæði smættun og heildarsýn. 
Smættarhyggja og heildarhyggja birtast með ýmsum öðrum hætti í matsfræðum en hér hefur verið rakið, pótt allt beri að sama brunni; petta má til dæmis sjá í samhenginu milli greiningar (e. analysis) og heildrænnar nýmyndunar (e. synthesis) í pekktu flokkunarkerfi námsmarkmiða sem kennt er við Benjamin Bloom og félaga (Anderson og Krathwohl, 2001). Orðin ,analysis“ og „,synthesis“ eiga rætur í forngrísku og merkja annars vegar pað „að hluta sundur í smærri einingar" og hins vegar að , , $ð$ tengja saman í eina heild“. Í matsfræðum er jafnan rætt um pað fyrra sem hæfni til að flokka og aðgreina, en pað síðara sem hæfni til að tengja saman fyrirbæri og setja fram á skapandi hátt (Waugh og Gronlund, 2013). Pótt skapandi hugsun og par með heildrænni nýmyndun sé hampað töluvert nú á dögum, á meðan smættarhyggjusjónarmiðinu virðist vera hafnað að nokkru marki, til dæmis með andstöðu við samræmd lokapróf, má leiða að pví rök að pessi tvö sjónarmið haldist í hendur pegar best lætur. Par nægir að vísa í umfjöllun núgildandi aðalnámskrár fyrir skyldunám um hæfni. Samkvæmt henni er pað á ábyrgð skóla að útfæra hæfni nemenda og mat á henni innan hverrar námsgreinar og skýra í skólanámskrá. Samhengið milli sundurgreindrar pekkingar og leikni annars vegar og heildrænnar hæfni hins vegar er útskýrt pannig:

Dekking, leikni og hæfni eru lykilhugtök í aðalnámskrá grunnskóla [...] Dekking er safn staðreynda, lögmála, kenninga og aðferða. Hún er bæði fræðileg og hagnýt [...] Leikni er bæði vitsmunaleg og verkleg. Hún felur í sér að geta beitt aðferðum, verklagi og rökréttri hugsun. Hæfni felur í sér yfirsýn og getu til að hagnýta pekkingu og leikni [...] Hæfni gerir kröfu um sköpunarmátt, ábyrgð og virkni.

(Mennta- og menningarmálaráđuneyti, 2013, bls. 39)

En hvað átti Lagemann raunverulega við með pví að Thorndike hefði unnið en Dewey tapað? Раð hefur lengi verið pekkt viðkvæði, að kennarar og aðrir skólamenn ,fylgi Dewey í orði, en Thorndike á borði“ (Atli Harðarson, 2016; Fesmire, 2015). Detta hafa fjölmargir sagnfræðingar og heimspekingar, sem hafa rannsakað sögu menntunar á Vesturlöndum, staðfest líkt og Lagemann (sjá t.d. Cremin, 1961; Kliebard, 1986; Peters, 1977; Zilversmit, 1993). Öllum ber saman um að peir atburðir sem áttu sér stað um miðja síðustu öld hafi skipt sköpum í pessu tilliti. Atli Harðarson vitnar í heimspekinginn Steven A. Fesmire pegar hann skýrir pessa próun svo, að tæknihyggja hafi nád yfirhöndinni:

Á árunum milli 1940 og 50 varð Dewey-ismi að samnefnara fyrir ágalla slaks menntakerfis ... Рað var á pessum árum, í kringum miðbik aldarinnar, sem námskrárfræði í anda Bobbitts urðu ríkjandi i Bandaríkjunum.Áhrifamesti talsmaður peirra var Ralph W.Tyler (1902-1994). Meginatriði í stefnu Tylers birtist á blaðsíðu 1 í bók hans frá 1949 sem heitir Basic Principles of Curriculum and Instruction ... Skemmst er frá pví að segja að frá miðri síðustu öld hefur stefna Tylers farið sigurför um Bandaríkin og síðustu áratugi hefur hún líka lagt menntakerfi Evrópu að fótum sér, meðal annars gegnum svokallað Bologna-ferli par sem eitt lykilhugtakið er pað sem á ensku kallast „learning outcome“. Hér á landi birtist pessi stefna meðal annars í Aðalnámskrá framhaldsskóla sem kveður á um að hver einasti námsáfangi sé skipulagður til að nemendur nái fyrirframskilgreindri pekkingu, leikni og hæfni og í almennum hluta Aðalnámskrár grunnskóla par sem orðið „hæfniviðmið“ kemur fyrir 210 sinnum eða að jafnaði nánast á hverri síðu.

(Atli Harðarson, 2015, bls. 4)

Pannig má ætla að smættarhyggja með áherslu á sundurgreinda markmiðssetningu að hætti Thorndikes og Tylers hafi nád yfirhöndinni pegar leið á 20. öldina. Við námskrárgerð og námsmat hafi slík hugmyndafræði haft vinninginn fram yfir heildarhyggju allt fram á okkar daga. Hugtökin hæfni og hæfniviðmið eru lykilhugtök nú á dögum og námskrá okkar er yfirfull af sundurgreindum hæfniviðmiðum í námsgreinum skyldunáms. 
Colin J. Marsh (2009, bls. 272) heldur pví einmitt fram að markviss skriffinnska og stöðlun náms og mats hafi einkennt próun skólastarfs frá aldamótum og fram á 21. öldina. Dessu eru pó ekki allir sammála. Allt frá lokum síðustu aldar hafa aðrir námskrárfrææingar, til dæmis Kelly (2009) og Pinar (2005), keppst við að varpa ljósi á galla hins staðlaða kerfis og haldið pví fram að pað væri að renna sitt skeið. Arfur Thorndikes hefur verið gagnrýndur harðlega og kaldhæðni ekki spöruð í peim efnum. Pinar nefndi til sögunnar orð eins og „,élagsverkfræði“ og „,manneskjuverkfræði“, orð sem sjálfur Thorndike hafði notað á priðja áratug síðustu aldar og hélt pví fram að slík tæknihugsun virtist ,gera rád fyrir að menntun sé eins og flókin vél ökutækis: ef við stillum allt rétt - kennslu, nám og námsmat - pá muni hún mala og flytja okkur á áfangastað, til hins fyrirheitna lands einkunna og einkunnagjafar" (Pinar, 2005, bls. 67, pýðing höfundar).

\section{Innleiðing núgildandi aðalnámskrár}

Í albjóðlegu samhengi má ljóst vera að leitin að jafnvægi milli smættunar og heildrænnar sýnar á námsskipulag hefur verið ljóslifandi í almenna skólakerfinu og hefur verið um langt skeið, eins og glögglega kemur fram í greinasafni Havnes og McDowell, Balancing Dilemmas in Assessment and Learning in Contemporary Education (2008). Svipaða stöðu mátti greina í niðurstöðum Rúnars Sigpórssonar (2008), sem gáfu til kynna að íslenskir kennarar stæðu frammi fyrir eins konar valpröng við að fylgja annars vegar ákvæðum aðalnámskrár og par með peirri heildrænu sýn sem í peim fólust og hins vegar samræmdum prófum með áherslu á smættun frekar en heildræna sýn. Niðurstöður Larry Cuban um athafnir kennara í bandarískum skólum fyrr og nú (1992, 2009) póttu sérlega athyglisverðar í pessu ljósi. Dar kom í ljós að tilraunir kennara til að laga sig að pversagnakenndri blöndu skólapólitískra skilaboða ofan frá annars vegar og hins vegar hugmyndum sérfræðinga í uppeldi og menntun áttu sér langa og lærdómsríka sögu. Slíkar rannsóknaniðurstöður vekja óneitanlega spurningar um áðurnefnt viðkvæði pess efnis, að kennarar hafi fylgt Dewey í orði, en Thorndike á borði.

Gögnin sem hér er lagt út af eru erindin sem flutt voru á ádurnefndum málpingum Rannsóknastofu um námskrár, námsmat og námsskipulag (NNN). Miðað við erindin, sem flutt voru á málpinginu 30. apríl, bendir margt til að leitin að áðurnefndu jafnvægi milli smættunar og heildrænnar sýnar hafi einkennt túlkunina á ákvæðum núgildandi aðalnámskrár undanfarin ár. Eins og síðar verður vikið að voru framsögumenn pó alls ekki samhljóða í afstöðu sinni til pessarar meintu glímu. Vegna hinnar pversagnakenndu blöndu skilaboða er ekki fráleitt að spyrja hvort leitin að jafnvægi parna á milli reynist jafnan erfiðari en margir telja? Um leið sé hún pó gagnleg og mikilvæg miðað við afstöðu Huldu:

Í grunninn pá er ég eiginlega pakklát af pví að fyrir mér pá eru petta ekki endilega boð um að ég eigi að gera petta á einhvern ákveðinn réttan hátt, heldur voru petta boð um að próa með mér aukna fagmennsku, að ég horfði virkilega á pað sem skipti máli [...] og petta [ferðalag] færði okkur brjálæðislega innihaldsríkar og stundum líka hávaðasamar samræður á kaffistofunni, á leiðinni pangað, á leiðinni paðan í tíma, jafnvel eftir kennslu, tár og allt mögulegt ...

(NNN Rannsóknastofa, 2019)

Hefur slík glíma ef til vill alltaf verið til staðar? Getum við ályktað sem svo að leitin að sanngjörnu og réttmætu námsmati, par sem gætt sé slíks jafnvægis, hafi ævinlega verið kennurum prautaganga samanber eftirfarandi orð eins helsta sérfræðings á pessu sviði: „Fullyrða má að fátt vefjist meira fyrir kennurum í dagsins önn en hvernig best verði staðið að námsmati, pannig að fyllstu sanngirni sé gætt." (Ingvar Sigurgeirsson, 1999, bls. 148).

Í fyrirlestri Jan van den Akker á málpinginu 25. mars, The Interconnected Curriculum, kom fram hvernig hnattvæðing segir til sín í vaxandi mæli, jafnt á sviði menntamála sem öðrum sviðum. Pannig mætti greina gagnvirkar tengingar (e. interconnections) á öllum stigum kerfisins, 
allt frá alpjóðlegum straumum ættuðum frá stofnunum eins og UNESCO, OECD og Evrópusambandinu yfir í pólitíska stefnumótun einstakra ríkja og innleiðingu hennar. Skoði maður grunnpætti og lykilhæfni má glöggt sjá að núgildandi aðalnámskrá hér á landi ber keim af bæði alpjóðlegum straumum og pólitískum áherslum pess stjórnmálaafls sem pá hafði stjórn menntamála hér á sinni könnu. Líkt og víða erlendis er par jafnframt talað um heildstæða menntun allt lífið, að proska sjálfsvitund, efla gagnrýna hugsun og frumkvæði og að gera nemendur að virkum pátttakendum í lýðræðissamfélagi (Mennta- og menningarmálaráðuneytið, 2013, bls. 86-87) sem purfi að öðlast getu til aðgerða og verða færir um að skipuleggja pátttöku í aðgerðum sem fela í sér úrbætur í samfélaginu (bls. 169).

Van den Akker benti einnig á að menn væru ekki á einu máli um hversu mikil samræmingin og samfellan skyldi vera pegar kæmi að námskrárpróun frá einu stigi yfir á annað (sjá töflu 1). Detta kom einnig fram í erindi Rúnars Sigpórssonar (NNN Rannsóknastofa, 2019). Van den Akker útskýrði stig kerfisins með líkani sem víða hefur verið notað í ýmsum myndum. Par vísaði hann í samhengið milli helstu stiga kerfisins: „supra (albjóðlegar áherslur), macro (bjóðarnámskrá/ aðalnámskrá), meso (skólanámskrá), micro (starfið í skólastofunni) og nano (upplifun, námsárangur og reynsla nemenda)“. Í okkar samhengi er sjónum beint að aðalnámskránni (macro) og innleiðingu hennar yfir á næstu stig fyrir neðan (meso, micro og nano) (tafla 1). Баð kom fram hjá öllum fyrirlesurum fundanna að námskrárbreytingar innan svona kerfis reyndust erfiðari en mörgum sýndist í fyrstu og tækju jafnframt mun lengri tíma en menn ætluðu.

Tafla 1. Samhengi námskrárbróunar yfir helstu stig kerfisins innan hvers lands. Byggt á van den Akker (2003).

\begin{tabular}{|c|c|c|}
\hline \multirow{2}{*}{$\begin{array}{c}\text { Etlaða/áformaða námskráin } \\
\text { (e. intended curriculum) }\end{array}$} & Hugsjónir & Sýn/meginhugmyndir (e. rationale) \\
\cline { 2 - 3 } & Formlegt/skrifað & $\begin{array}{c}\text { Áform eins og pau birtast í skrifuðum } \\
\text { stefnuplöggum, aðalnámskrá }\end{array}$ \\
\hline \multirow{2}{*}{$\begin{array}{c}\text { Virka/innleidda námskráin } \\
\text { (e. implemented/enacted } \\
\text { curriculum) }\end{array}$} & Túlkun & $\begin{array}{c}\text { Pað hvernig kennarar og aðrir skilja } \\
\text { og túlka opinberu námskrána }\end{array}$ \\
\cline { 2 - 3 } & Framkvaemd & $\begin{array}{c}\text { Nám og kennsla samkvæmt hinni } \\
\text { virku skólanámskrá }\end{array}$ \\
\hline \multirow{2}{*}{$\begin{array}{c}\text { Upplifða/lærða námskráin } \\
\text { (e. attained/experiential } \\
\text { curriculum) }\end{array}$} & Námsreynsla & Reynsla og upplifun nemenda sjálfra \\
\cline { 2 - 3 } & Námsárangur & Raunverulegur námsárangur \\
\hline
\end{tabular}

Samkvæmt alpjóðlegri samanburðarrannsókn, sem van den Akker vann fyrir námskrár- og námsmatsstofnun Írlands (NCCA) á árunum 2017-2018, kom ítrekað fram að víða um lönd hefði innleiðing nýrrar námskrár krafist meiri undirbúnings, tíma og faglegs stuðnings en menn ætluðu í fyrstu (NNN Rannsóknastofa, 2019).

Á málpinginu 30. apríl tók Rúnar Sigpórsson svo til orða, að umræða um námsmat væri alltaf flókin. Бað er pví ekki sjálfgefið að fagvitund kennara dugi ævinlega til að leysa öll álitamál við innleiðingu hins nýja matskerfis. Um innleiðinguna sagði Rúnar: „Баð er að mínu viti bagalegt hversu losaralega pessum viðamiklu og að mörgu leyti flóknu breytingum sem mælt var fyrir um í núgildandi aðalnámskrá var fylgt eftir og hversu fátt við í rauninni vitum um hvernig framkvæmdin er vítt og breitt um landið ...“ (NNN Rannsóknastofa, 2019). Jón Pétur Zimsen bar innleiðinguna hér saman við innleiðinguna í Svípjóð; par hefðu verið gerð myndbönd sem skýrðu fyrir kennurum hugmyndirnar að baki matskerfinu og stór hópur fólks hefði farið í skólana og aðstoðað við innleiðinguna. Ekki voru pó allir á sama máli um mikilvægi slíkrar eftirfylgni. Hulda Proppé sagðist pvert á móti fagna pví að innleiðingin, eða öllu heldur stýringin ofan frá, hefði verið eins veik og raun bar vitni. Hún rökstuddi pað pannig, að petta hefði veitt henni og samstarfsfólki faglegt sjálfstæði, sem hefði eflt pau í starfi sínu við að próa og útfæra matskerfið með sínum hætti, samanber tilvitnun hér á undan. 
Um leið sagðist hún hlynnt sveigjanleika og sjálfstæði skóla og hafnaði par með samræmingu, enda væri hún ekki við hæfi með petta matskerfi að leiðarljósi. Loks sagðist hún skilja vel að petta kerfi gerði mönnum erfitt að meta nemendur inn í framhaldsskóla, en pað væri hins vegar ekki sitt hlutverk að mæta pörfum framhaldsskólans miðað pað kerfi sem par væri viðhaft, heldur væri nær að framhaldsskólinn tæki upp pau vinnubrögð sem fælust í hæfnimatskerfi grunnskólans.

\section{Hæfni, hæfniviðmið og matsviðmið}

Hér er fjallað um lykilhugtök tengd innleiðingunni. Höfundur taldi óhjákvæmilegt að vísa reglulega til enskra orða yfir pessi hugtök vegna fræðilegs uppruna peirra og merkingar. Til dæmis er hætta á að orðið „hæfniviðmið“ pyki merkingarsnautt án tengingar við uppruna pess, p.e. erlendu orðin „competence“ og „learning outcomes“. Orðið „,ærdómsviðmið“ hefur einnig verið notað yfir sama hugtak (sjá Kennslumiðstöð Háskóla Íslands, e.d.). Dví má bæta við að pað er notað í námskeiðslýsingum við Háskólann í Reykjavík.

Í fyrirlestri sínum minntist van den Akker ítrekað á hversu mikilvægt væri að tala skýrt um samhengið milli markmiða eða hæfniviðmiða námskrárinnar annars vegar og námsmatsins á öllum stigum kerfisins hins vegar. Til að skýra nánar ferlið frá hinni áformuðu námskrá yfir í virku og lærðu námskrárnar og pað hvernig smættun og heildarsýn birtast gegnum pað ferli hlýtur pví að vera brýnt að skýra nánar hugtökin „hæfni“ og „hæfniviðmið“ og hina miklu athygli, sem pessi hugtök hafa hlotið hér undanfarin ár. Athyglina má rekja til pátttöku Íslands í svonefndu Bologna-ferli Evrópusambandsins. Markmið pess ferlis var að samræma skipulag æðri menntunar hvað varðaði námstíma, námseiningar (ECTS) og síðast en ekki síst hæfnikröfur. Samræmingu hæfnikrafna átti einmitt að innleiða með setningu samstilltra hæfniviðmiða (sjá nánar Kennslumiðstöð Háskóla Íslands, e.d.). Dátttaka Íslands í Bologna-ferlinu var meðal annars staðfest með auglýsingu um útgáfu viðmiða um æðri menntun og prófgráður (nr. 530/2011). Dótt pessi samræmingaráætlun Evrópusambandsins hafi pannig beinst fyrst og fremst að æðri menntun, færðust hugmyndir og hugtök á lægri skólastig einnig, eins og skýrt má greina í núgildandi aðalnámskrám grunnskóla og framhaldsskóla.

Til að skilja hugtakið „hæfniviðmið“ og beitingu pess er í raun óhjákvæmilegt að tengja pað við pau orð á erlendum málum sem Evrópusambandið og ýmis lönd nota, p.e. „learning outcomes“ á ensku (Kennslumiðstöð Háskóla Íslands, e.d.) og „Lernergebnisse“ á pýsku. Bæði erlendu orðin vísa til námsárangurs eða námsafraksturs, eins og „learning outcome“ var pýtt í Orðaskrá Kennaraháskóla Íslands um mat og próffræði (Rannsóknarstofnun Kennaraháskóla Íslands, 2000). Orðið hæfniviðmið er pví umdeilanleg pýðing par sem erlendu orðmyndirnar hafa í raun lítið með viðmið að gera. Hvað sem öðru líður pá hefur orðið náð að festast hér í sessi og pví mikilvægt að skoða hvernig pað tengist hugtakinu hæfni (e. competence), jafnt í skrifum um Bologna-ferlið sem og í pví hvernig fjallað er um pað í aðalnámskrá hérlendis.

Stephen Adam við Háskólann í Westminster (Adam, 2008) hefur fjallað ítarlega um Bologna-ferlið. Hann lýsti tilkomu pessara hugtaka í námskrárpróun innan Evrópu sem grundvallarstefnubreytingu og líkti henni við pað pegar Thomas Kuhn (1962) lýsti umskiptum (e. paradigm shift) í hugmyndum manna um raunvísindi. Adam bætti við að samhengið milli pessara tveggja hugtaka hefði reynst flókið í meðförum, umdeilt og valdið margvíslegum ruglingi (2008, bls. 8). Sumir hneigðust til að heimfæra pau á ýmiss konar víðtæka og heildræna hæfileika, sem pætti óraunhæft að reyna að mæla eða meta hlutlægt. Aðrir litu á pau frá mun prengra sjónarmiði og vildu pannig tengja pau við pjálfun og tileinkun pekkingar par sem hæglega mætti mæla eða meta árangurinn hlutlægt líkt og verklega færni í iðnnámi; annaðhvort kynni nemandi eða kynni ekki. Dessu til viðbótar benti Adam á að pýðingar úr einu tungumáli á annað hefðu valdið ruglingi og fyrir bragðið hefði merking hugtaka orðið enn óskýrari en ella. Höfundur pessarar greinar telur að slíkt hafi gerst að nokkru marki hér á landi. Í pýðingu núgildandi aðalnámskrár yfir á ensku er orðið hæfniviðmið - sem fyrst var valið sem pýðing á „learning outcomes“ - til dæmis nú pýtt sem „,competence criteria“. Sami vítahringurinn virðist hafa skilað sér inn í íðorðasafn um menntamál (Stofnun Árna Magnússonar í íslenskum fræðum, e.d.). 
Í próffræðum er beiting pessara hugtaka að vísu nokkuð skýr. Par eru „learning outcomes“, sem við nefnum á íslensku hæfniviðmið, sett fram með hliðsjón af flokkun námsmarkmiða, til dæmis flokkunarkerfi Blooms og félaga (Waugh og Gronlund, 2013, bls. 71-72). Hæfniviðmið eru pá sett fram með virkum sögnum (e. active verbs eða action verbs) sem lýsa pví hvað nemandi á að pekkja, skilja, kunna eða vera fær um pegar námsferli lýkur (tafla 2).

Tafla 2. Flokkun markmiða og hæfniviðmið. Byggt á Waugh og Gronlund (2013).

\begin{tabular}{|c|c|}
\hline Flokkur markmiða & Dæmi um virkar sagnir fyrir hæfniviðmið (e. learning outcomes) \\
\hline Dekking - minni & Man, skilgreinir, lýsir, listar upp, velur, útskýrir \\
\hline Skilningur & Tengir, útskýrir, túlkar, spáir fyrir um, flokkar \\
\hline Beiting & Sýnir, reiknar, leysir, skipuleggur, tengir, beitir \\
\hline Greining & Aðgreinir, hlutar sundur, raðar, skipar í kerfi \\
\hline Nýmyndun - skapandi hugsun & Skapar, setur í nýjan búning, tengir saman, semur, byggir upp \\
\hline Mat - gagnrýnin hugsun & Leggur mat á, gagnrýnir, réttlætir, ályktar, leiðir í ljós \\
\hline
\end{tabular}

Баð аð lýsa hæfni pannig með virkum sögnum er ekkert annað en lýsing á atferli og matið pví augljóslega atferlismiðað. Dess vegna telur Adam rökrétt að rekja pá ákvörðun að nota orðasambandið „learning outcomes“ um eina öld aftur í tímann, p.e. til sálfræðinga á borð við B. F. Skinner og J. B. Watson.

Vart má skilja við umræðuna um hæfni og hæfniviðmið án pess að gefa námsgreinum, námssviðum og inntaki peirra gaum, enda er skýrt samhengi milli markmiða og inntaks peirra annars vegar og hæfniviðmiða og námsmats hins vegar eins og pað er kynnt í námsgreinahluta námskrárinnar fyrir skyldunám (Mennta- og menningarmálaráðuneytið, 2013, bls. 84-232). Samkvæmt 7. kafla núgildandi laga um grunnskóla skal setja ákvæði í aðalnámskrá um inntak og skipulag helstu námsgreina og námssviða. Par segir:

Dess skal gætt að námið verði sem heildstæðast, en hver grunnskóli ákveði hvort námsgreinar og námssvið eru kennd aðgreind eða sampætt. Í aðalnámskrá skal skilgreina pekkingar- og hæfnipætti á hverju námssviði. Nemendur skulu eiga pess kost að uppfylla námsmarkmið einstakra námsgreina og námssviða með mismunandi hætti. Í aðalnámskrá skal setja árangursviðmið um pað hvenær nemandi telst hafa lokið einstökum námsgreinum eða námssviðum ... I aðalnámskrá skal gera grein fyrir samstarfi grunnskóla við leikskóla og framhaldsskóla og hvernig skuli staðið að aðlögun og flutningi milli skólastiga.

(Lög um grunnskóla nr. 91/2008, 25. grein)

Við petta má bæta að samkvæmt aðalnámskrám grunn- og framhaldsskóla eru inntak og viðfangsefni skólastarfsins sett fram í námssviðum, námsgreinum eđa námsáföngum, en í almennum hluta fyrir grunnskóla segir: „Rétt er að hafa í huga að námssvið, námsgreinar og námsáfangar eru ekki markmið í sjálfu sér heldur hjálpartæki til að stuðla að merkingarbæru námi og ná markmiðum skólastarfsins“ (Mennta- og menningarmálaráđuneytið, 2013, bls. 13). Hér er ýmislegt vert nánari athugunar, t.d. hvað felst í orðalaginu ,inntak og skipulag helstu námsgreina og námssviða“ "í lögunum og með hvaða hætti námskráin kveður á um pessi atriði. Í erindi sínu benti Jón Pétur Zimsen á að sænsk skólayfirvöld hefðu í vaxandi mæli gefið inntakinu gaum með pví að reyna að skýra betur en áđur hvaða pekkingu skyldi leggja áherslu á í námsgreinum, afmarka betur inntakið svo pað virkaði ekki of umfangsmikið og gefa skýrari skilaboð um hvað skyldi numið og kennt í hverjum árgangi.

Loks má spyrja hvað átt var við með pví í lögunum að námið skyldi verða „sem heildstæðast og frjálst hvort námsgreinar eru kenndar sampættar eða aðgreindar". Má ef til vill skilja petta sem 
ótta námskrárhöfunda við að námið verði ekki nógu merkingarbært, leggi menn of ríka áherslu á að skipa pví niður á greinasvið og áfanga?

\section{Faglegt sjálfstæði kennara og tilgangur námsmats}

Á fundi með Kennarasambandi Íslands vísaði Atli Harðarson meðal annars til faglegs sjálfstæðis kennara (Atli Harðarson, 2015), sem var ekki að ástæðulausu. Námskrárpróun jafnt hér sem erlendis ber pess merki, að fagleg ábyrgð á inntaki og skipulagi náms hafi í vaxandi mæli færst á herðar kennara og stjórnenda hvers skóla. Рað á ekki hvað síst við um námsmat og framkvæmd pess; pað er nú alfarið á ábyrgð skóla að votta um árangur nemenda við lok skyldunáms. Í pví sambandi má benda á ólík sjónarmið peirra Jóns Péturs og Huldu hvað varðaði samræmingu inntaks og mats. Jón Pétur lét í ljós áhyggjur af pverrandi samræmingu á meðan Hulda sagðist fagna sjálfstæði skóla við að útfæra nám og námsmat með sínum hætti. Innleiðing pess hæfnimatskerfis, sem núgildandi aðalnámskrá kveður á um, hlýtur pví að standa og falla með pví hvernig kennarar og aðrir hagsmunaaðilar skilja pað og túlka, hvort sem pað er samræmt eða ekki.

Enginn ætti pví að velkjast í vafa um að fagleg ábyrgð peirra, sem stjórna ferðinni í pessum efnum innan veggja skólanna, er mikil. Deim er ætlað að taka inn í myndina margvíslegan tilgang og aðferðir námsmats. Nú er gert ráð fyrir að kennari beiti mati til að örva hugsun nemenda um eigið nám, styðja við námið og stuðla pannig að aukinni virkni og áhuga, sem gera má ráð fyrir að leiði til aukins námsárangurs:

Mat á árangri og framförum barna og ungmenna er reglubundinn páttur í skólastarfi, órjúfanlegur frá námi og kennslu. Megintilgangur námsmats er að veita leiðbeinandi upplýsingar um námið og hvernig markmiðum pess verður náð. Með námsmati er fylgst með pví hvernig peim tekst að ná almennum hæfniviðmiðum aðalnámskrár, stuðlað að námshvatningu, nemendur örvaðir til framfara og metið hvaða aðstoð peir purfa.

(Mennta- og menningarmálaráđuneytið, 2013, bls. 27)

Megintilgangur námsmats í grunnskóla er með öðrum orðum leiðsögn og stuðningur við nám og kennslu og að mati margra samofið námi og kennslu pegar best lætur eins og kom skýrt fram í erindi Rúnars (NNN Rannsóknastofa, 2019). Hin faglega ábyrgð kennara og stjórnenda nær pó lengra; tilgangurinn er einnig sá að votta um árangur náms og kennslu við lok námstíma og veita öllum hagsmunaaðilum áreiðanlegar og réttmætar upplýsingar um stöðu og framvindu náms:

Námsmat á einnig að veita nemendum og foreldrum peirra, kennurum, viðtökuskólum og skólayfirvöldum upplýsingar um námsgengi nemenda, hæfni peirra, vinnubrögð og framfarir, sem m.a. má hafa að leiðarljósi við frekari skipulagningu náms.

(Mennta- og menningarmálaráðuneytið, 2013, bls. 54)

Tilgangurinn er pví jafnframt sá að afla traustra gagna um hæfni nemenda, túlka pau með hliðsjón af settum viðmiðum og birta á viðeigandi hátt sem vitnisburð um námsgengi og námsárangur. Pótt tilgangur námsmats geti verið margvíslegur, tíðkast pví að tala um tvenns konar megintilgang, annars vegar leiðsögn samofna námsferlinu og hins vegar vottun um árangur við lok námsferlis; pað fyrra nefnum við leiðsagnarmat (e. formative assessment) og pað síðara lokamat eða samantektarmat (e. summative assessment). Hvort tveggja krefst vandaðs námsmats og 1 báðum tilvikum skipta hugtökin áreiðanleiki (e. reliability) og réttmæti (e. validity) sköpum, að minnsta kosti pegar skyldunámi lýkur: „Grunnskólinn er ábyrgur fyrir pví að um réttmætt og áreiðanlegt mat sé að ræða við lok grunnskóla“ (Mennta- og menningarmálaráðuneytið, 2013, bls. 57).

Faglegar ákvarðanir kennara og stjórnenda sem sérfræðinga byggja vissulega á reynslu í starfi (praxis) og peim sérstæðu aðstæðum sem peir starfa við. Jafnframt verður að gera ráð fyrir að 
par sé byggt á rannsóknum og kenningum (teoríu). Samkvæmt samanburði Black og Wiliam á námsmatskerfi fjögurra landa (2005) er reyndin jafnframt sú, að hugmyndafræði, skólamenning og skólapólitík ráđa hér ekki síður ferðinni en reynsla og fræðileg pekking. Detta birtist m.a. í pví hvernig námsmat tengist á mismunandi hátt kröfunni um ábyrgð og árangur (e. accountability) og pví hvernig samspil leiðsagnarmats og lokamats birtist með mismunandi hætti.

Í ákvæðum núgildandi aðalnámskrár um skyldunám kemur skýrt fram, að megintilgangur námsmats í skyldunámi er að veita leiðbeinandi upplýsingar um námið og styðja pannig við framvindu pess (Mennta- og menningarmálaráðuneytið, 2013). Slíkt leiðsagnarmat hlaut vaxandi athygli um heim allan eftir að bresku sérfræðingarnir Paul Black og Dylan Wiliam (1998a, 1998b) birtu samantekt sína skömmu fyrir síðustu aldamót um rannsóknaniðurstöður sem póttu sanna gildi pess að hafa matið innbyggt í námsferlið og styðja pannig við áframhaldandi nám með markvissri endurgjöf (e. feedback/feed-forward). Black og Wiliam drógu saman niðurstöður yfir 250 rannsókna úr ýmsum áttum og töldu niðurstöðurnar staðfesta að leiðsagnarmat hefði jákvæðari áhrif á námsárangur en svonefnt lokamat.

Uppruna enska hugtaksins ,formative assessment“ má rekja aftur til sjöunda áratugar síðustu aldar. Michael Scriven (1967) notaði pað líklega fyrstur, reyndar ekki um mat á námsframvindu einstakra nemenda, heldur mat á kennslu og námskrám. Um svipað leyti notuðu Benjamin S. Bloom og félagar pað hins vegar með svipuðum hætti og pekkist nú á dögum (Bloom, 1968; Bloom, Hasting og Madaus, 1971). Síðan hafa fjölmargir rannsakað, skrifað og fjallað með ýmsum hætti um pennan tilgang mats. Par má meðal annars greina að framkvæmd leiðsagnarmats er vandasöm og getur verið tvíeggjuð, til dæmis pegar kemur að endurgjöf. Í umfangsmikilli rannsókn Kluger og DeNisi (1996), sem var framkvæmd á svipuðum tíma og rannsókn Black og Wiliam, fundust dæmi pess að virkni endurgjafar (e. feedback) í daglegu skólastarfi gat haft neikvæð áhrif jafnt eins og jákvæð. Detta gerðist til dæmis pegar endurgjöfin beindist að einstaklingnum sjálfum frekar en verkum hans eða pegar hún fælist 1 formlegri einkunnagjöf eða umbun af einhverju tagi. Samkvæmt sömu niðurstöðum virtust meiri líkur á jákvæðum afleiðingum pegar rætt væri við nemendur um verk peirra og hvernig mætti skoða nánar pað sem betur mætti fara í stað pess að benda einungis á pað með hrósi eða gagnrýni hvað hefði verið gert vel og hvað ekki.

Eins og pegar hefur verið rætt er tilgangur námsmats pó ekki einungis endurgjöf og stuðningur við nám og kennslu. Tilgangurinn er einnig að veita öllum hagsmunaaðilum skólastarfsins áreiðanlegar upplýsingar um námsgengi og námsárangur, p.e. að votta um námsstöðu út frá gefnum viðmiðum. Í hefðbundnum skilningi er nemandi skráður í fyrirfram skilgreint nám, sem lýkur fyrr eða síðar með formlegu lokamati og vottun um námsárangur (e. accreditation). Ef horft er aftur í tímann er ljóst að tæknihyggja eða tækniræði (e. technocracy) hefur ósjaldan ráðið hér ferðinni, par sem nám og kennsla hafa verið hugsuð sem línuleg framvinda stýrð af skilgreindu inntaki og ætluðum afrakstri náms (sbr. e. expected learning outomes). Útkoman (e. product) var jafnan lögð undir mælistikur nefndar „próf“ og niðurstöður birtar sem „einkunnir“.

Frá gildistöku fræðslulaga 1946 og fram til ársins 1974 má segja að slíkt mat hafi ráđið ferðinni hér á landi; pað birtist sem eins konar dýrkun á bóknámskunnáttu undir merkjum hins svokallaða „landsprófs“ ásamt „,barnaprófum“ og „fullnaðarprófum“ (Ólafur J. Proppé, 1999). Upphafleg hugmynd landsprófsins hafði reyndar verið ,,jafnrétti til bóklegs náms“ sem myndi opna leiðir til æðra náms, en pað varð brátt að eins konar „námskrá fyrir allt skólakerfið“ og að margra mati ljón í vegi eðlilegrar skólapróunar. Hugmyndin að baki fræðslulögunum hafði verið að próa skólakerfi við hæfi allra, m.a. með vali milli bóknáms og verknáms, sem skyldi verða framfaraspor og mæta kröfum samfélagsins og breytilegum pörfum nemenda. Sú hugsjón virðist pó hafa snúist upp í andhverfu sína (Ólafur J. Proppé, 1999).

Í niðurstöđum lokamats felst samantekt mælds eða metins námsárangurs. Í erindi sínu lét Rúnar 1 ljós pá skoðun að nær væri að tala um samantektarmat frekar en lokamat og vísaði par til réttmætis í peim skilningi að ein mæling í lok námstíma, t.d. skriflegt lokapróf, dygði ekki til að gefa 
gilda mynd af hæfni nemanda. Svipuð ábending kom fram í erindi Sverris sem benti á að lokapróf gæti aldrei orðið annað en púsl í stærra heildarsamhengi. Rúnar lét einnig í ljós pá athyglisverðu skoðun að óheppilegt væri að stilla lokamati upp sem andhverfu leiðsagnarmats:

Ég tel að lokamat eigi líka að nota til leiðsagnar og að lokamat sé í raun illframkvæmanlegt nema á grundvelli vandaðs leiðsagnarmats. Hér skiptir sumsé máli hvernig við komumst að peim niðurstöðum sem við birtum nemendum og forráðamönnum sem vitnisburð um hæfni nemenda. Til pess að pessi vitnisburður sé réttmætur, að hann gefi rétta mynd af hæfni nemenda, parf að safna margvíslegum gögnum samhliða leiðsagnarmati [...] Pannig haldast í mínum augum lokamat og leiðsagnarmat í hendur og eru tvær hliðar á sama teningi frekar en andstæður. Og pá nálgast pað kannski pað sem felst í enska hugtakinu summative, p.e. summan af einhverju eða heildaryfirlit.

(NNN Rannsóknastofa, 2019)

Á sínum tíma varaði sjálfur John Dewey við tvíhyggjuhugsun af pví tagi sem Rúnar vísar hér til (e. thinking in either-ors) og lagði pess í stað til að menn nýttu styrk beggja og par með pað sem gagnaðist hverju sinni með tilliti til sannrar menntunar (1938, bls. 90). Fjölmargir sérfræðingar hafa rannsakað og leitt að pví rök, líkt og Rúnar, að nýta megi lokamat í págu leiðsagnarmats og öfugt (sjá t.d. Harlen, 2008; Maxwell, 2004; Stiggins, Arter, Chappuis og Chappuis, 2004). Hvað sem öðru líður bera kennarar og stjórnendur ábyrgð á víðtæku mati á hæfni, par sem tilgangurinn er bæði stuðningur við nám og kennslu og einnig að votta um árangur við lok námstíma. Deir geta pví að minnsta kosti fagnað pví að víða er að finna gagnleg skrif um pað viðfangsefni, jafnt rannsóknir og fræðileg skrif sem og hagnýt ráð um starfið í skólastofunni.

\section{Samantekt og ályktanir}

Í inngangskafla var ýjað að pví að matskerfi pað, sem kynnt var til sögunnar í núgildandi $A$ ðalnámskrá grunnskóla (Mennta- og menningarmálaráđuneytið, 2013), væri í raun ekki nýjung heldur ný heiti á hugtökum og hugmyndum sem við pekktum fyrir, p.e. „,gamalt vín á nýjum belgjum“. Pannig mætti færa fyrir pví rök að hæfniviðmið samsvari í meginatriðum inntaki og markmiðum námssviða og námsgreina, sem námskrár hafi kveðið á um gegnum tíðina. Jafnframt er minnt á, að tengingin við mismunandi flokka í flokkunarkerfum námsmarkmiða er skýr, til dæmis við flokkunarkerfi Blooms og félaga (Anderson og Krathwohl, 2001).

Pó má ljóst vera að kennarar og aðrir upplifa matskerfið sem meginbreytingu, sem gerir kröfu um aukna faglega ábyrgð kennara og pá grundvallarspurningu hvort hæfniviðmið, inntak námsgreina og par með námsmat skuli vera samræmt á landsvísu eða ekki. Spurningin snýst nánar tiltekið um pað hvort kennarar og skólar ættu að vera samstiga í pessum efnum eða hvort hver og einn kennari ætti að taka mið af aðstæðum og nemendahópnum sem hann hefur hverju sinni líkt og kom fram í erindi Huldu Proppé á seinna málpinginu. Ætti kennari að velja hæfniviðmið og par með viðfangsefni eftir pörfum, samhengi og aðstæðum hverju sinni? Ætti hann pá að haga matinu í samræmi við pað? Á seinna málpinginu mátti greina skiptar skoðanir í pessum efnum sem vöktu óneitanlega erfiðar spurningar.

Hlýtur ekki að purfa að taka inn í myndina samfelluna milli skólastiga, sem er einmitt lögð áhersla á í núgildandi aðalnámskrám allra skólastiga? Hvernig ber að túlka ákvæði pess efnis að veita purfi „nemendum og foreldrum peirra, kennurum, viðtökuskólum og skólayfirvöldum upplýsingar um námsgengi ..." (Mennta- og menningarmálaráđuneyti, 2013, bls. 54)? Hver ættu pá viðmiðin að vera? Samkvæmt ákvæðum gildandi aðalnámskrár parf matið jafnframt að vera bæði áreiðanlegt og réttmætt. Рað vekur einnig spurningar um hversu skýr skilaboð námskrárinnar ættu að vera. Jón Pétur kallaði eftir skýrari ákvæðum, aðalnámskráin pyrfti að vera: 
... góður leiðarvísir, góð handbók sem kennarar grípa og lesa og geta farið eftir, en eins og staðan er í dag, svo ég vitni í minn gamla læriföður Hilmar Hilmarsson, pá er hún svona meiri ráđgáta heldur en hún ætti að vera.

(NNN Rannsóknastofa, 2019)

Miðað við alla umræðuna, bæði á málpinginu og úti í skólakerfinu, virðist veruleikinn sá að miðlæg samræming ríki ekki í íslensku skólakerfi, hvorki um túlkun og beitingu hæfniviðmiða aðalnámskrár né heldur um inntak og par með fyrirkomulag námsmats. Dess vegna verður að ákvarða hversu skýrt samhengi purfi að ríkja milli námskrárprepanna priggja (sjá töflu 1), ætluðu námskrárinnar (e. intended curriculum), virku námskrárinnar (e. enacted curriculum) og síðast en ekki síst reynslu og námsárangurs nemenda (e. attained/experiential curriculum) í pessum efnum eða ekki. Í pví sambandi er vert að hafa ábendingar Black og Wiliam (2005) í huga pess efnis að hugmyndafræði og pólitík ráđa ekki síður ferðinni í pessu samhengi en reynsla og fræðileg pekking, samanber umræðuna um áhrif Dewey eða Thorndike, smættun eða heildarsýn. Í pví sambandi má einnig nefna áhrif erlendra strauma á ákvæði um grunnpætti, lykilhæfni, heildstæða hæfni og fleira.

Orðanotkun tengd námsmati virðist vera á reiki og skilningur fólks á hugtökum par af leiðandi ekki skýr. Dað kom til dæmis fram í erindi Lindu Heiðarsdóttur að peir, sem kæmu að innleiðingu matskerfisins, virtust rugla saman hugtökum og hugmyndum, sem liggja peim til grundvallar og orðalag hæfniviðmiða væri oft pað hástemmt að jafnvel kennarar skildu pað varla, hvað pá nemendur og forráðamenn peirra. Sumir hefðu pví farið í að endurskrifa hæfniviðmiðin til að gera pau nemendavænni, sem væri pó hæpið pví pá væru kennarar farnir að leggja vinnu í að túlka og endurskrifa aðalnámskrána til að hún skildist betur út frá peirra sjónarmiði. Hafa parf par í huga að túlkun getur verið afstæð og einstaklingsbundin. Að mati Lindu virtist orða- og hugtakaruglingur ná til allra meginhugtaka námskrárinnar, p.e. hæfni, hæfniviðmiða, matsviðmiða, lykilhæfni og grunnpátta. Sterk tilhneiging til að rugla saman hæfniviðmiðum og matsviðmiðum væri í raun töluverður vandi. Benda má í pví sambandi á tilvitnun í skrif Stephen Adam hér á undan, sem benda til að slíkur ruglingur sé ekki séríslenskt fyrirbrigði.

Minnst var á skrif Ellen Condliffe Lagemann (1989) pess efnis að til að skilja sögu menntunar á 20. öld pyrfti að átta sig á að Thorndike hefði unnið en Dewey tapað. Ef skólastarf hér á landi væri skoðað nú, pegar nærri tveir áratugir eru liðnir af nýrri öld, kæmi án efa í ljós að átökin milli pessara tveggja hugmyndastefna reyndust ljóslifandi sem aldrei fyrr undir margs konar merkimiðum, t.d. átökunum milli atferlishyggju og hugsmíðahyggju. Skoði maður sögu menntunar á síðustu öld og fram á pessa er engu líkara en pessi átök hafi verið látlaus í langan tíma, í að minnsta kosti 100 ár, og engan veginn ljóst hvort hafi í raun nád yfirhöndinni. Ef sveiflur í umgjörð og innihaldi opinberrar námskrár á Íslandi væru rannsakaðar frá einum tíma til annars, mætti eflaust leiða að pví líkum að pennan stöðuga bardaga mætti skoða sem forsendu námskrárpróunar, drifkraft pendúlhreyfinganna.

Van den Akker komst að peirri niðurstöðu að námskrárpróun væri flókið ferli sem væri erfitt að henda reiður á og tæki langan tíma. Hann notaði einnig pekkta samlíkingu Larry Cuban pess efnis að á öllum tímum hömuðust einhverjir við að gára yfirboðið, líkt og óveður og fellibyljir gera við yfirborð hafsins, en í undirdjúpunum gengi allt sinn vanagang eins og endranær. Í pví sambandi parf að hafa í huga samhengið milli peirra priggja prepa námskrárpróunar sem áđur var lýst (tafla 1). Líkt og Rúnar gaf til kynna í fyrirlestri sínum, pá er allt of lítið vitað um hvernig framkvæmdin er vítt og breitt um landið, p.e. hvort eða hvernig hin opinberu fyrirmæli, sem sett eru fram í aðalnámskrám á mismunandi tímum, skila sér yfir í virku og upplifðu námskrárnar. Væri pað til dæmis hugsanlegt að finna skóla hér árið 2019, sem fylgdi einhvers konar sambræðingi markmiða og hæfniviðmiða úr fleiri en einni námskrá, jafnvel úr peim öllum; 1960, 1976, 1989 og 1999? Mögulega ögn af pví sem núgildandi aðalnámskrá boðar? 
Meginályktun sem höfundur pessarar greinar telur að megi draga af peim álitamálum tengdum innleiðingu nýs matskerfis, sem hér hafa verið reifuð, er eftirfarandi: Hugmyndin um víðtæk hæfniviðmið og hæfnimat hlýtur að stuðla að auknu réttmæti miðað við pað sem áður pekktist og par með réttlátara mati öllum til hagsbóta. Hins vegar krefst matið mun meiri vinnu en áður og meira bókhalds og um leið má vænta að pað verði huglægara en áður og jafnvel óreiðukenndara, ekki samræmt. Dað krefst aukinnar ábyrgðar kennara og annarra, sem hlut eiga að máli, og um leið markvissrar matsfræðipekkingar, sem vart má ætla að sé alls staðar fyrir hendi sem skyldi. Prátt fyrir ákvæði í lögum um ytra og innra eftirlit með skólastarfi er ekki að vænta annars en að fólk lendi á villigötum við eftirlit með mati, par sem viðmið reynast á margan hátt óskýr. Í kerfi par sem kennarar geta valið viðfangsefni og hæfniviðmið eins og af hlaðborði, og jafnvel samið ný hæfniviðmið, er erfitt að sjá hvernig haga má gæðamati eða eftirliti með námsmati.

\section{Issues related to the implementation of a new assessment system in compulsory education}

Historically, the development of assessment and evaluation in Icelandic public education has been similar to that of other Nordic countries, featuring an amalgamation of knowledge transmission, testing and relative grading, on the one hand, and, on the other, an open plan promoting formative assessment focused on processes rather than products of learning. At some points in time the pendulum has swung towards achievement assessment with an emphasis on transmission of knowledge to be measured, and, at other times, it has swung towards an emphasis on learning as a metacognitive activity featuring a student-centred curriculum.

In 2013 new national curricula were issued for compulsory schools and secondary schools. The assessment system presented in the curriculum for compulsory education has been severely criticised due to ambiguous information about its key concepts and how it is supposed be implemented. Teachers appear to have been uncertain as to the purpose of assessment, while facing difficulties in collecting data about multiple competences and reporting their results. According to the curriculum stipulations, teachers and school administrators are solely responsible for all assessment, both formative assessment aiming at supporting learning and motivating students and summative assessment aiming at delivering reliable and valid information about learning outcomes and achievement. Furthermore, teachers and scholars argue about standardisation, and to what extent learning outcomes, contents and assessment ought to be synchronised across the school system or not standardised at all.

The Centre for Curriculum, Assessment and Learning (NNN Research Centre) at the School of Education sponsored two open seminars in spring 2019 where the focus was placed on discussing various issues related to the implementation of the curriculum. The first seminar was held in March, where Jan van den Akker, a Dutch curriculum specialist, opened the debate with an introductory lecture called The Interconnected Curriculum. He discussed the complex context and relations between the different levels of the curriculum system; that is, supra, macro, meso, micro, and nano. Although professionals may argue about this system's linear organisation, van den Akker emphasised the importance of clear information about assessment and its continuous alignment between different levels. He also pointed out that, according to his research findings, curriculum amendments and the implementation of new ideas needed time and professional support to a greater extent than most people presume.

The second seminar was at the end of April 2019. There, five Icelandic education professionals, a university professor, two school administrators, one school teacher and a director from the Directorate of Education, discussed issues and alleged problems relating to the implementation of the new assessment system. An interesting controver- 
sy cropped up in their discussion as to how far the assessment system with its learning outcomes and assessment criteria should be centralised or standardised, concerning contents and subject learning objectives. The discussion also focused on the responsibilities of teachers and their increasing assessment-related workload. According to the national curriculum, teachers and schools have shouldered more responsibility for both summative and formative assessment than ever before. Indeed, combining those two has become a major task through assessment strategies embedded in learning and teaching, such as authentic assessment, performance-based assessment, self-assessment, peer-assessment, and feedback.

The discourse on competences, learning objectives, and learning outcomes gave the impression that all this controversy was actually about 'old wine in new bottles', reminding us of the old debate as to whether education has actually been controlled by ideas rooted in John Dewey's theories or Edward Thorndike's philosophy. As education historian Ellen Condliffe Lagemann (1989) had observed: 'One cannot understand the history of education in the United States during the twentieth century unless one realizes that Edward L. Thorndike won and John Dewey lost.' Hence she indicated that the history of education has in fact been about how the education system has favoured psychometrics and standardised testing while giving mainly lip-service, as Arthur Zilversmit put it (1993), to child-centred curricula with an open plan. Assessing various learning outcomes separately clearly reflects reductionism according to Thorndike's ideas, while assessing competences as a whole favours holism in accordance with the Deweyan perspective. A careful analysis of the current national curriculum in Iceland reveals an emphasis on both systems of thought. Thus it may be debatable which of the two, Thorndike or Dewey, won the battle of Icelandic curriculum development.

The author's main conclusion is that wide-ranging learning outcomes and assessment criteria, as stipulated in the official curriculum, theoretically present a more valid and reasonable evaluation for the benefit of all students. This approach, however, demands extensive professional responsibility and knowledge of assessment theory from teachers and administrators. Simultaneously it must be realised that, in the absence of a centralised assessment system, all competence criteria have become open to flexible interpretation.

Key words: Curriculum implementation, assessment, competence, learning outcomes, summative assessment, formative assessment

\section{Um höfund}

Meyvant Dórólfsson (meyvant@hi.is) er dósent við Menntavísindasvið Háskóla Íslands. Hann lauk meistaraprófi frá Kennaraháskóla Íslands árið 2002 og doktorsprófi frá Háskóla Íslands árið 2013. Helstu viðfangsefni og rannsóknarefni hans eru á sviði námskrárfræða og námsmats. Meyvant hefur einnig tekið pátt í rannsóknum og próunarverkefnum á sviðum stærðfræði og náttúruvísinda í íslensku skólakerfi.

\section{About the author}

Meyvant Pórólfsson (meyvant@hi.is), Associate Professor at the School of Education, University of Iceland. He completed an MA in education from Iceland School of Teacher Education in 2002 and a PhD in education from the University of Iceland in 2013. His research interests are in the fields of curriculum theory and assessment. $\mathrm{He}$ has also been involved in research and projects relating to mathematics and science education. 


\section{Heimildir}

Adam, S. (2008). Learning outcomes current developments in Europe: Update on the issues and applications of learning outcomes associated with the Bologna process. Edinburgh:The Scottish Government.

Anderson, L.W. og Krathwohl, D. R. (2001). A taxonomy for learning, teaching and assessing: A revision of Bloom's taxonomy of educational objectives. Boston, MA: Allyn \& Bacon.

Atli Harðarson. (2015). Stefna í námskrármálum og faglegt sjálfstcoði kennara [erindi fyrir fundi Kí 14. og 21. okt. 2015]. Sótt af https://www.ki.is/images/Skrar/KI/Forystufraedsla/2015/Atli_Hardarson.pdf

Atli Harðarson. (2016). Lýðræði og menntun: Hugleiðing um aldargamla bók. Netla - Veftímarit um uppeldi og menntun. Sótt af http://netla.hi.is/greinar/2016/ryn/01_ryn_arsrit_2016.pdf

Auglýsing um útgáfu viðmiða um æðri menntun og prófgráđur nr. 530/2011.

Black, P., og Wiliam, D. (1998a). Assessment and classroom learning. Assessment in Education: Principles, Policy E Practice, 5(1), 7-73.

Black, P. og Wiliam, D. (1998b). Inside the black box: Raising standards through classroom assessment. Phi Delta Kappan, 80(2), 139-149.

Black, P. og Wiliam, D. (2005). Lessons from around the world: How policies, politics and cultures constrain and afford assessment practices. The Curriculum Journal 16(2), 249-261. doi:10.1080/09585170500136218

Bloom, B. S. (1968). Learning for mastery. Instruction and curriculum [Regional Education Laboratory for the Carolinas andVirginia,Topical Papers and Reprints, no. 1]. Sótt af https://files.eric.ed.gov/fulltext/ED053419.pdf

Bloom, B. S., Hastings, J. T. og Madaus, G. F. (1971). Handbook on formative and summative evaluation of student learning. New York: McGraw-Hill.

Cremin, L. A. (1961). The transformation of the school: Progressivism in American education, 1876-1957. New York: Alfred A. Knopf.

Cuban, L. (1992). How teachers taught: Consistency and change in American classrooms 1890-1980. New York: Longman.

Cuban, L. (2009). Hugging the middle: How teachers teach in an era of testing and accountability. New York:Teachers College Press.

Dewey, J. (1938). Experience and education. New York: Collier Books, Macmillan.

Elmore, R. F., og McLaughlin, M.W. (1988). Steady work: Policy, practice, and the reform of American education. Santa Monica: Rand Corporation.

Fesmire, S. (2015). Dewey. New York: Routledge.

Fullan, M. G. (1989). Implementing educational change: What we know. Ottawa: Education and Employment Division. Population and Human Resources Department.

Fullan, M. G. (2001). The new meaning of educational change (3. útgáfa). New York: Teachers College Press.

Fullan, M. og Hargreaves, A. (1991). Working together for your school. Melbourne: Australian Council for Educational Administration.

Gossen, D. (2001). Restitution: restructuring school discipline. Chapel Hill, NC: New View.

Hargreaves, A. og Fink, D. (2006). Sustainable leadership. San Francisco: Jossey-Bass.

Hargreaves, A., og Fullan, M. (2012). Professional capital:Transforming teaching in every school. New York: Teachers College Press.

Harlen, W. (2008). Teachers' summative practices and assessment for learning - Tensions and synergies. Í W. Harlen (ritstjóri), Student assessment and testing (bls. 292-308). London: Sage.

Havnes, A. og McDowell, L. (2008). Balancing dilemmas in assessment and learning in contemporary education. New York: Routledge.

Ingvar Sigurgeirsson. (1999). Námsmat byggt á traustum heimildum ... Í Helgi Skúli Kjartansson, Hrafnhildur Ragnarsdóttir, Kristín Indriðadóttir og Ólafur J. Proppé (ritstjórar) Steinar í vörðu, til heiðurs Duríði J. Kristjánsdóttur sjötugri (bls. 147-169). Reykjavík: Rannsóknarstofnun Kennaraháskóla Íslands.

Jón Pétur Zimsen. (2019). Niðurstöður könnunar á innleiðingu núgildandi aðalnámskrár [erindi flutt á Menntakviku 4. október 2019 í málstofu NNN-rannsóknastofu um innleiðingu nýs námsmatskerfis]. 
Kelly, A.V. (2009). The curriculum: Theory and practice. Los Angeles: Sage.

Kennslumiðstöð Háskóla Íslands. (e.d.). Hæfniviðmið (lærdómsviðmið). Sótt af https://kennslumidstod.hi.is/ kennarar/nam-og-kennsla/skipulag/haefnividmid-laerdomsvidmid/

Kliebard, H. M. (1986). The struggle for the American curriculum 1893-1958. Boston: Routledge \& Kegan Paul.

Kluger,A. N. og DeNisi,A. (1996). The effects of feedback interventions on performance:A historical review, a meta-analysis, and a preliminary feedback intervention theory. Psychological Bulletin 119(2), 254-284. doi:10.1037/0033-2909.119.2.254

Kuhn, T. S. (1962). The structure of scientific revolutions. Chicago: University of Chicago Press.

Lagemann, E. C. (1989). The plural worlds of educational research. History of Education Quarterly, 29(2), 185-214. doi:10.2307/368309.

Lög um grunnskóla nr. 91/2008.

Marsh, C. J. (2009). Key concepts for understanding curriculum. New York: Routledge, Taylor \& Francis Group.

Maxwell, G. S. (2004). Progressive assessment for learning and certification: Some lessons from school-based assessment in Queensland [fyrirlestur á 3. ráðstefnu Association of Commonwealth Examination and Assessment Boards í Nadi, Fiji].

Mennta- og menningarmálaráđuneytið. (2013). Aðalnámskrá grunnskóla:Almennur hluti 2011: Greinasvið 2013. Reykjavík: Höfundur.

NNN Rannsóknastofa. (2019). Málping haldið 30. apríl 2019. Upptöku frá málpinginu er að finna hér: https://hi.cloud.panopto.eu/Panopto/Pages/Viewer.aspx?id=9faa7c55-af2d-4c87-9a92-aa3e00b407b3

Ólafur Proppé. (1999). Dróun samræmdra prófa í íslenskum skólum frá 1880-1977. Í Helgi Skúli Kjartansson, Hrafnhildur Ragnarsdóttir, Kristín Indriðadóttir og Ólafur J. Proppé (ritstjórar), Steinar í vörðu. Til heiðurs Durídi J. Kristjánsdóttur sjötugri (bls. 137-146). Reykjavík: Rannsóknarstofnun Kennaraháskóla Íslands.

Perricone, C. (2006). The influence of Darwinism on John Dewey's philosophy of art. The Journal of Speculative Philosophy, New Series, 20(1), 20-41.

Peters, R. S. (1977). John Dewey's philosophy of education. Í R. S. Peters (ritstjóri), John Dewey reconsidered (bls. 102-121). London: Routledge \& Kegan Paul.

Pietarinen, P., Pyhältö, K. og Soini, T. (2017). Large-scale curriculum reform in Finland - exploring the interrelation between implementation strategy, the function of the reform, and curriculum coherence. The Curriculum Journal, 28(1), 22-40. doi:10.1080/09585176.2016.1179205

Pinar,W. (2005). The problem with curriculum and pedagogy. Journal of Curriculum and Pedagogy 2(1), 67-82.

Rannsóknarstofnun Kennaraháskóla Íslands. (2000). Orðaskrá um skólamál og sálar- og menntafreeđi: Mat og próffreeði [Orðanefnd Kennaraháskóla Íslands tók saman]. Reykjavík: Höfundur.

Rúnar Sigpórsson. (2008). Mat í págu náms eða nám í págu mats: Samremd próf, kennsluhugmyndir kennara, kennsla og nám í náttúrufreeði og íslensku í íslenskum skólum (doktorsritgerð). Kennaraháskóli Íslands, Reykjavík.

Scriven, M. (1967). The methodology of evaluation. Í R. E. Stake (ritstjóri), Curriculum evaluation (bls. 39-83). Chicago: Rand McNally.

Stiggins, R. J., Arter, J. A., Chappuis, J., og Chappuis, S. (2004). Classroom assessment FOR student learning: Doing it right—using it well. Portland, OR: ETS Assessment Training Institute.

Stofnun Árna Magnússonar í íslenskum fræðum. (e.d.). Íðorðabankinn: menntunarfreðði. Sótt af http://idord. arnastofnun.is/leit//ordabok/MENNTUNARFR

Sugai, G. og Horner R. H. (2009). Defining and describing schoolwide positive behavior support. Í W. Sailor, G. Dunlap, G. Sugai og R. Horner (ritstjórar), Handbook of positive behavior support. Issues in clinical child psychology (bls. 307-326). Boston, MA: Springer.

van den Akker, J. J. H. (2003). Curriculum perspectives: An introduction. Í J. van den Akker, W. Kuiper og U. Hameyer (ritstjórar), Curriculum landscape and trends (bls. 1-10). Dordrecht: Kluwer Academic.

Waugh, C. K. og Gronlund, N. E. (2013). Assessment of student achievement. Upper Saddle River, NJ: Pearson.

Zilversmit, A. (1993). Changing schools: Progressive education theory and practice, 1930-1960. Chicago: The University of Chicago Press. 
Netla - Veftímarit um uppeldi og menntun:

Sérrit 2019 - Menntakvika 2019

Meyvant Dórólfsson. (2019).

Álitamál tengd innleiðingu hæfnimiðaðs námsmats í skyldunámi

Netla - Veftímarit um uppeldi og menntun. Menntavísindasvið Háskóla Íslands.

Sótt af http://netla.hi.is/serrit/2019/menntakvika_2019/03.pdf

DOI: https://doi.org/10.24270/serritnetla.2019.44 